\title{
The Re-alignment of Post-Secondary Education Systems in Canada
}

\author{
ALEXANDER GREGOR*
}

\begin{abstract}
This paper is concerned with the attempts that have been made in Canada during the 1960 's and 1970's to define and develop systems of post-secondary education to include the various forms of institutions at that level (i.e., the universities, community colleges, technical institutes, etc.). Particular emphasis is placed on the attempts to define the appropriate relationships between the universities and the relatively new community college sector. Attention is given to the quite different nature of that latter sector in the various provincial jurisdictions, and to the more general issues that must be addressed in any attempt to co-ordinate institutions based on quite different goals and natures. The paper concludes that there are very clear limits that must be observed in any efforts to produce efficient and co-ordinated systems of higher education, if violence is not to be done to the basic nature and purposes of the constituent institutions.
\end{abstract}

\section{RÉSUMÉ}

Le réalignement des systèmes d'enseignement post-secondaires au Canada

Dans cette étude, il s'agit des tentatives faites au Canada au cours des années 60 et 70 de définir et de développer des systèmes d'enseignement post-secondaires qui englobent la gamme possible d'institutions à ce niveau (par ex. universités, collèges communautaires, instituts techniques, etc.) On met surtout l'accent sur les tentatives de définir les rapports apporpriés entre les universités et le secteur relativement nouyeau des collèges communautaires. L'auteur porte son attention sur la nature assez difféerente de ce dernier secteur dans les diverses jurisdictions provinciales et sur les questions de portée plus générale auxquelles il faut s'adresser dans toute tentative de coordonner des institutions fondées sur des natures et des objectifs assez différents. La conclusion de l'auteur est qu'il existe des limites très claires qu'il faut observer dans tout effort de faire valoir des systèmes efficaces et coordonnés d'enseignement supérieur si l'on ne veut pas violer la nature et les objectifs de base des institutions ainsi englobées.

*Department of Educational Administration and Foundations, The University of Manitoba. 
In introducing a paper in 1975 dealing with recent reports of various provincial postsecondary commissions, Gordon Campbell made the following observation:
Historians may well judge the advent of community colleges to be the most dramatic and visionary of many astonishing developments, during the past fifteen years, in Canadian post-compulsory education. It is especially tantaliz- ing to reflect upon the assessment that historians may make of the relationships spawned between these new colleges and the universities. Universities have shaped the mind and character of an elite; the inception of community colleges marks in our society the beginning of a stage that regards universal access to post-school education as a paramount objective."

In conjunction with this sanguine forecast, Campbell makes what he calls an assumption, that "systems' do exist in every province at the tertiary level.. .." 2 The use of the rubric "system" to describe post-secondary education in the Canadian provinces would provide considerable anxiety to an analytic philosopher. There are perhaps "systems" within the components of the provincial institutions: among the universities, on the one hand, and among the community colleges, on the other; and, indeed, there may be "system", in the sense of an aggregate of parts more-or-less answering collectively the demands made for post-secondary study. But the public's wishful thinking that needs to see an ordered whole answering in some truly co-ordinated fashion that full spectrum of social needs, flounders on the rocks not just of practicality but also of principle. "System" may be desirable, from the point of view of social planning, but almost inevitably its imposition does violence to the character of the institutions included within that system. Indeed the danger is a very real one that the essential character of the university seems almost inevitably to be ignored when the institution is viewed as part of a social-service "system". Such warning is implicit in, for example, the report of an Ontario Commission: ". . postsecondary education is coming, to some extent, to be regarded as a consumer good ..." 3

This dilemma arises from the circumstances that bought the community colleges into being during the last two decades, and from the fact that quite different and not always compatible purposes lie behind their establishment. The motivations were partly indigenous to Canada, and partly an importation of foreign approaches to post-secondary education, these being principally American. The balance of these factors was, of course, quite different in the various provinces, and because education is a provincial jurisdication, the result was a very varied range of "systems". The central factor in this spectrum will be the roles defined for the new community college sector and the resulting relationship those roles will entail in terms of the relationship the colleges will have to the universities within the provincial jurisdiction. It has been this defining of roles that has produced, in some areas, community colleges with a character quite close to the American junior college, with a consequent intimate relationship with the provincial universities; and in other areas the community colleges are quite deliberately limited to technical and technological training that by definition limits severely any significant relationship with the university. (The "systems" of Alberta and Manitoba demonstrated those two extremes, with the other "systems" occupying stations between them on the spectrum. Next to Alberta, for example, would be British Columbia; next to Manitoba would be Ontario.) The "added ingredient" that brought the Alberta end of the spectrum into the junior college mode was issues of accessibility to post secondary education, and regionalism. As in the United 
States, the argument was a persuasive one that students geographically removed from universities might justifiably be provided with at least the junior years at a local level, postponing the expensive move to a university ${ }^{4}$ to the more specialized senior years. ${ }^{5}$ Beside this argument was one that argued that distinct regions unblessed by a local university should at least be entitled to a college that would reflect local needs and be an identifiable centre for local students. These roles expanded substantially the mandate of the colleges and made them quite different from those at the Manitoba end where the issues of accessibility and regionalism were not felt to be germane, or at least not something that had to be answered by a college format.

The central issue that emerges in each of the provincial systems and is determined by the role assigned to the community colleges, is reflected in the matter of transfer of credit. The report of the Ontario Commission identifies the principle and implies some of the difficulties:

To be accessible, flexible, and diverse, our educational system must also provide individuals with opportunities to transfer from institution to institution or from program to program. This does not imply a rejection of quality, standards, or an automatic prescription of admissibility. The opportunity for transfer must exist; a screen should not become a barrier, and perhaps some chances must be taken in individual cases. ${ }^{6}$

Except in those situations (as for example in British Columbia and Nova Scotia), where an alternate approach has been attempted of having university courses taught by extension in college permises, certain common questions arise.

Can transfer of credit from college to university, which is a matter of necessity in a junior college format, and which arises as a demand, sui generis, even in those relatioships where it was not originally intended, exist without doing some damage to the nonunversity purposes of the colleges? A 1974 report of the British Columbia Task Force on the Community College had this to say, for example:

\begin{abstract}
... colleges should be viewed as an alternative to the university or technological institute rather than an institutional form that is imposed between the school system and the university. Thus, colleges should no more defer to the universities than schools should defer to the colleges. Each type of educational institution should provide different and distinct learning experiences, with none viewed as better or worse, higher or lower, than the other. Each type of institution should simply provide a true alternative.
\end{abstract}

While none of the other provinces would disagree with this sentiment, Manitoba at least would argue that arrangements for transfer of credit (in cases other than specific junior college work) will inevitably compromise the college programs to the intent of causing the colleges to do things which they consider inappropriate. As an example, the Manitoba college authorities would argue that an attempt to make their technological programs "transferable" would require the infusion of a "general education" component that could only dilute the content of the basic skills training. "While this "compromise" will not be a problem in those jurisdictions in which the colleges are quite clearly intended to teach the first two years of university course work (as in Alberta and British Columbia), it can be in jurisdictions in which the general education component is not meant to duplicate the course structure of the university (as in Ontario), or, in yet another variation (such as 
Newfoundland) where there has been a desire to have the two-year academic component of the colleges acting, at the same time, as a terminal general education and as a foundation to a university degree. ${ }^{9}$ In only one province is the problem effectively avoided by having the colleges a stepping-stone to the universities, as well as something discrete in themselves (the Quebec CEGEPS).

There is a certain ironic element in all this. While governments wish to preserve the unique character of the community colleges, they will often see association with the university as a means of increasing the traditional status of those non-university institutions. ${ }^{10}$

To some extent the situation can be mollified by having the college programs compartmentalized, with the university-transfer stream kept quite separate from the technological programs, for example. But any attempt to maintain vigorously such a dichotomy is doomed to the same failure as the parallel attempt made in some jurisdictions to maintain a firm discreteness between universities and community colleges. The pedagogical principles run afoul of over-riding social policies, which are reflected in the demand appearing in all of the recent provincial task forces on post-secondary education, namely accessibility. Such a policy can cause universities to offer admission and advance standing to professional studies on the basis of work quite different in kind from that of the university and to people who are in some quite authentic ways unqualified. If such transfers are on a small scale, as they are now, there are few consequences except to the individual student. If they increase in volume, as indeed they may if the colleges and universities are brought into closer co-ordination in professional training, then a very real pressure would begin to be exerted on the college programs to bring them into closer symmetry with those of the university, in terms both of content and admission requirements. Then would appear again that vacuum the colleges were in fact intended to fill in the first place, and the "homogenization of post-secondary institutions" that all the provinces attempted to avoid.

The problems that exist in the articulation of college and university programs are not always a result of provincial philosophies of education but rather of quite external factors over which the provinces have little control. Principal among these are the licensing requirements of the trades and professions with which the colleges are charged, and the constraints of Federal funding. The latter consideration is particularly interesting. While education per se is quite clearly a provincial responsibility, the federal government has assumed a central role in manpower training. During the last decade this has been carried out in large part in a rather indirect fashion by the Federal department's "purchasing" a certain number of places in the trades and technical/technological components of the provincial community colleges or technical institutes, and allocating those spaces to the students it is undertaking to train or retrain. This so-called "joint cost-sharing" approach of the current Liberal government (initiated by the one-time Minister of Manpower and Immigration, Jean Marchand) observed the letter of the law in the matter of provincial/ federal relations. But in fact the trades and technical/technological components of the colleges can become quite dependent on the federal purchases and therefore amenable to shaping the programs according to Manpower demands (in terms of admission criteria, content, program length, etc.). In Manitoba, for example, the Oliver Task Force on PostSecondary Education quite specifically recommended that the colleges decrease their almost symbiotic link with Canada Manpower, but no such change has taken place, nor 
is it considered imminent. The reason is principally one of practicality, but there seems to be little anxiety on the part of the provincial authorities to alter the situation.

The implications are rather significant in terms of college-university relationships. Importantly, the college's technological offerings will be presented as programs rather than as individual courses. The programs are meant to be immediately responsive to the work world, and so are in a constant state of adjustment, with this adjustment lengthening, shortening or altering the components or courses within the programs. This situation, though eminently justifiable and desirable in terms of manpower preparation, obviates the sort of stability required for formal interdigitation of college and university programs. There is no practical possibility, for example, of the college program being utilized as the first one or two years of a profesisonal training completed at the university level. An example is to be seen in the problems faced by professional schools at the University of Manitoba in assessing advance standing to be accorded on the basis of college work. The actual content of each course must be examined for each student as the constant change prevents the course title itself from being used in successive years as an indicator of precise content and duration; and because of the overall program changes, the university is not able to assume that a particular theoretical foundation has been established. For this reason it can only offer standing invarious elective credits running through its own program, rather than in any block of theoretical work per se.

But the problem is more even than flux in program content. More fundamental perhaps, is a basic and intentional difference in kind between college and university courses (with the exception, again, of the junior college type transfer courses). In the case of technical and technological courses, college authorities have scrupulously insisted on a fundamentally different approach to teaching. In Manitoba, for example, there is the quite deliberate contention that the issues of "academic freedom", the "critical mind", and a "general theoretical basis" are not germane to the aims and purposes of the colleges, regardless of the abilities of the college teaching staff. There is not to be the tension that is maintained in the university between being simultaneously a professional training school and a university faculty. The college, quite naturally, is seen as having the role of reflecting the training perceived as necessary by the profession; there is not the requirement of providing a critical theory that in the university is considered part of the liberal basis of professionalism - a theory that is intended quite deliberately to place the individual professional and the professional faculty of the university at odds, from time to time, with the accepted tenets and practices of the profession. Quite explicably, it is assumed that the college graduates will not have to exercise the same level of professional decision-making responsibility as the university graduate. In contrast to the university, then, the college approach is perceived as rather conservative and "anti-intellectual" in the sense of having some impatience with what the college perceives as an overly-theoretical approach on the part of the university staff. This difference in attitude leads to obvious difficulties in discussions related to course development, program articulation, etc. The province's quite deliberate and justifiable policy of keeping the colleges "un-university-like" proves to be consistent with the inclination of a portion of the college staff, and inconsistent with the inclination of other portions. There seem to be three general groupings within the colleges. These stand in a rather competitive stance, so it is more difficult to speak of a college teaching staff perspective than it is to speak of an administrative perspective. The groupings are: 
first, the technical areas, which have very much an industry (rather than university) orientation; second, the technological areas, which have an interest in connections with the universities, but just in advanced technological (i.e. vocational) training; third, there are the professional areas, which have a claim to association with groups receiving professional education in the same areas at the university level. (These may be such areas as teaching, nursing, social work, etc.) But even here, however, attempts at integrating programs become haunted almost immediately by the differences in professional perspective alluded to previously. An example may be found in the case of integrated teacher education program established, by government fiat, between the University of Manitoba and the province's principal community college. Indeed, the problems that have been associated with this are particularly instructive, insofar as the college program in question is the least college-oriented and most university-oriented of any in the province. In fact, the program (which has to do with the training of Business and Industrial Arts Teachers) was situated at the college for practical rather than pedagogical reasons; that is where the expensive equipment was. But the very fact of being at the college caused the program to assume the orientation of that institution in contrast to the ethos of the university-based teacher training program. (This difference is reflected, typically, in a more conservative stance and the characteristic impatience with theory; in concrete illustration was an initial disagreement on the proportion of time that should be spent in each of the two institutions, and, therefore, in integration with the full body of prospective professionals.) The result is the persistance of a kind of "two-solitudes" in what is in theory a unified program. To this extent the integration is somewhat artificial, remaining two years of college and two years of university rather than four years of something new. With respect to college-university programs, then, it would appear that government fiat can dictate a marriage, but only something higher can make two become as one.

Regardless of the problems in the venture, however, it is illustrative of some of the pressures that will continue to play upon the government for such integrated programs, as long as the provincial governments maintain the important policy that community colleges not be degree-granting institutions. (The quite probable assumption is made that to make the colleges degree-granting bodies would be to internalize in them the very university influences that even now constantly threaten their basic purpose and character. The danger is well recognized of an almost innate tendency on the part of the different types of institution to take on areas of study that "properly" belong to others, "The need to monitor and co-ordinate to avoid unnecessary duplication of this sort is as great as the need to avoid unnecessary duplication among institutions within a group."12 ) The case of teaching training showed, however, that regardless of the actual adequacy of the college diploma for the professional needs of the groupd ebing trained, a bias within the profession itself tends to define status in terms of university training. The teachers who had received their training and credentials at the community college found themselves a caste apart in the public school system. Moreover they found the chances for professional development hindered by the lack of articulation between college and university programs. On both counts, a joint program seemed to be the only feasible answer.

When similar problems exist as well for other of the professions in the division between two discrete jurisdictions of responsibility for the training of different elements within the same profession, then logic would seem to lead to the idea that was seen emerging in the various provinces during the deliberations of their respective post-secondary task forces. 


\section{The Re-alignment of Post-Secondary Education Systems in Canada}

This was the proposal, that has yet to be acted upon in any comprehensive fashion, of having the colleges and universities linked into a "ladder" of professional training, running from technical to theoretical (as, for example, from paramedical to physician). But logic does not seem to be the guiding principle in answering the problems of college-university relations; the consensus seems to be that certain uneradicable difficulties make such a model an impossible dream. The major reason is seen to be the professions. The licensing autonomy of those groups, and their hold over accreditation of training, are seen as having the effect of limiting closer articulation between colleges and universities. Because the provinces' concern in this area is closely tied to larger social policy rather than just to education per se (as, for example, economic and social mobility for disadvantaged groups; more inexpensive and efficient matching of professional or technical skills and training to the actual needs of the market place in areas such as health care), there is a very real interest in the actions taken by two provinces, Quebec and Ontario, to limit somewhat the autonomy of the professional bodies, and at the same time to move to more rational and consistent definitions of levels within the professions. The assumption is made that these levels might in turn be matched by systematic gradations within the professional training programs. Ironically, it is recognized that real control of professional certification will require the involvement of the federal government. This increased involvement in the post-secondary systems of the provinces (except, of course in financial assistance) would be moving against the major tendencies of the day.

Quite apart from the question of the influence of the professions on college-university relationships, there are other factors which make the gradation model an unlikely one. There is a real problem in terms of prerequisites, with college students who are eligible to enter university programs on the basis of their college diploma work but who will, in many cases, not have the normal secondary-level university entrance courses, thereby encountering very real difficulties, particularly in the areas of mathematics and the sciences. Again, the very different programs of the colleges and universities exacerbate this problem. A technology program, for example, does not provide the base for university science and engineering courses. Moreover, this seems to be a problem endemic to the situation, insofar as "very flexible admission standards appear to be essential elements of all community colleges." $" 13$ None the less, the deficiency in skills and content makes the rather idealistic model of movement from skill training to technology and from technology to professional theory easier said than done.

An even more subtle problem is to be found in what some see as a social bias that creates an artificial "need" for university-level training for purposes of esteem and status, in situations where the actual needs of the job do not require it. This "status game", it is argued, can not only artificially inflate the requirements of programs that perhaps need not be at the university level in the first place; it can also create a bias against beginning the lower stages of professional training in an institution other than a university. (This point is, of course, open to question. The Nova Scotia University Grants Committee has taken a more sanguine view, seeing

... a changing attitude toward higher education. The degree, be it bechelor's, master's, or higher, is becoming less important for its own sake. The tendency to measure a man by his accomplishments rather than by his qualifications is growing. Hence there is greater tendency toward specialist education, particularly in the technologies, and this is best offered by the community colleges. ${ }^{14}$ 
Within this issue, however, is another that is frequently mentioned but little attended to, to, for reasons that will be explored later. That is the question of the proper and appropriate designation of roles and programs to the two sectors, university and college.

From yet another point-of-view, that of the university, the notion of having training gradations established below them, over which they have little control but to which they must accommodate their programs, can quite sincerely be viewed as threatening to the university's responsibilities in defining and defending the standards of professional education. On an even more general level, current fears induced by financial constraints mean that the universities must have assurance that acceptance of a more efficient integration would not occasion some quite conceivable inroads into institutional autonomy in priorities and resource allocations.

To take Manitoba as an example again, these fundamentally opposed perspectives have been in evidence in some rather acrimonious "discussions" in such areas as dental hygiene and nursing. These blocks to an integrated system can probably be resolved only by rather dramatic government action, and at the present time the actual public pressure is not large enough to make such action likely. It is interesting to note that in the technological areas the purported sizable "demand" for transfer programs that led to the establishment of the present limited provisions does not seem really to be there (At the University of Manitoba, for example, the affected faculties other than the special case of Education have only about 6 to 15 applicants each in a year.) But the question of why the expected demand did not materialize has not been properly posed. The colleges are aware that there is a number of students who for reasons of age, etc. are reluctant to continue their education at the university level. These students are therefore pressing the colleges to go into areas of general education which the administration has some serious doubts are appropriate. But clearly, some form of more comfortable transition is necessary if the proper roles of the two sectors are to be properly maintained.

An area of college-university relationship that has defied satisfactory solution to date is that of appropriate communication and liaison between the two sectors, and a coordinated planning and development of the total post-secondary system. The problem derives from the fundamental differences that exist between the two types of institution. In simplistic terms, the university has thus far succeeded in preserving most of its autonomy in program planning and content (subject, of course, to the traditional power of th purse). In the case of the community college, the same rationale for academic freedom does not obtain; rather than being an institution protected by the spirit of common law from state intervention, the community college is quite clearly seen as the agent of public policy. Almost by definition, that which is taught in the community colleges should reflect the will and wisdom of the society, and not stand in critical counterpoint to it. Similarly, the staff can be seen as under something of a mandate to teach in that spirit. (It may perhaps be suggested that this distinction lies at the base of any delineation of roles.) For this reason, the colleges are not seen to be self-determining or self-defining; planning is usually centralized in the provincial bureaucracy, with the college staff in effect (and in a case like Manitoba's, in fact) public servants; and normally they are excluded from the governing and senior policy-making machinery of the colleges.

Despite the difficulties such centralization can lead to within the colleges themselves, in such areas as staff morale, ${ }^{15}$ the provincial governments have shown little inclination 
to release their hold. In some jurisdictions, University Grants Committee-like buffer commissions were proposed and implemented for the community-college sector; in other areas, however, the connection is a direct and unmediated one. Moreover, as Cameron observes, there has been a more recent tendency on the part of governments even in the former areas to reduce in fact the limited autonomy that the colleges had initially received, in areas such as boards of governors and advisory committees.

According to them, an institution with too much autonomy gets aspirations of upward mobility (the university) to the neglect of the new constituencies colleges were created to serve. Moreover, the outstanding reputations achieved by institutions of technology in Western Canada managed from their inception by departments of education, destroys the argument that governments by definition stultify, and mismanage educational institutions. ${ }^{16}$

In Manitoba, for example, this has meant that no action has been taken on the 1974 recommendation of the Oliver Task Force that a mechanism be established (the Commission on Post-Secondary Education) for the co-ordination of the two sectors, this agency to be on the model of the existing Universities Grants Commission (that is, a "buffer" agency independent of direct government involvement). Consequently, planning has been carried out quite separately, with the continuing UGC having virtually no connection with the college sector. And the nature and role of the UGC itself makes impracticable any significant co-ordination even within the government department to which the UGC is, in its curious fashion, responsible. The mechanism for a provincial system (if that term is to imply detailed co-ordination) is therefore simply not available.

Campbel1 17 has introduced three categories of "system" which may be employed in examination of the other provincial jurisdictions. These he defines as unitary, binary and ternary. The unitary system appears only in Quebec where, as mentioned previously, the CEGEPS exist not as a parallel alternative form of post-secondary education, but rather as one of four levels within the provincial system. Thismakes unique whatever conclusions may be drawn about them, and not generally applicable to the situation in the rest of Canada.

The second category, 'binary' systems, applies to Manitoba, Ontario (the Colleges of Applied Arts and Technology), and to the Maritime Provinces. In the latter two cases, the colleges offer a broader range of programs and show more of a community orientation than do the colleges of Manitoba. Consequently, they have either individually or collectively, ${ }^{18}$ boards of governors to reflect the community viewpoint. But while this would mean a slight increase in institutional autonomy, the effect would not be in the direction of closer liaison with the universities; if anything, the effect would be in the opposite direction, insofar as the boards would be urging the colleges toward their community role. As is implied in the rubric, the provinces maintaining a binary system have insisted on a clear observation of the philosophical division between the two sectors.

The provinces of British Columbia, Alberta and Saskatchewan share variations of the ternary system. This approach is characterized by an attempt to "federate" the various institutional forms required at the post-secondary level into three broad and co-ordinated streams: the universities; the community colleges; and institutes of technology, agricultural colleges, etc. The presence of the third category affords a very important difference in comparison to the binary system. The removal of the technical/technological task from 
the community colleges significantly reduces the latter's need to be so scrupulously "un-university-like" as they must be under the binary system. As suggested previously, it has to an important extent been externally imposed standards (of, for example Manpower or trades licensing bodies) that have dictated the content and orientation of the programs. With this compulsion removed in part, the colleges are much more easily to be alligned to be alligned to the university in aspects oftheir content and orientation without the same threat of violence to the character of these other hand, those provincial systems that are on a binary system have, insofar as they allow any transfer, insisted that the transfer credit not be in the form of identical work, in content or format. The situation in Manitoba has already been discussed; the Ontario and Maritime approach is exemplified in the following statement from the 1972 report of the New Brunswick Higher Education Commission:

The colleges should not give courses designed to provide transfer credits equivalent to first or second year university programmes. If general or liberal arts courses were to be given by some colleges, these should be terminal courses leading to a diploma or certificate, and it should be left to the universities to decide whether they would give credit for them if a graduate should apply for admission to a university. ${ }^{19}$

In part, the problem arise from the laudable reluctance of the provincial governments to carry the creation of "systems" to its logical extreme. This reluctance has been voiced as well in the reports of the provincial commissions, as for example, in that of the Ontario Commission: ". . . we reject as irrelevant to the needs of Ontario the development of a monolythic, unitary system of post-secondary education directed from above. ${ }^{20}$ " Appropriate alternatives, however, are not easy to discover. The approach taken in several jurisdictions, as, for example, Ontario and Alberta, has been to establish independent advisory councils without administrative or executive authority. This device has value in terms of exchange of viewpoints and information, but obvious weaknesses in terms of actually implementing and co-ordinating changes within the system; significantly, the Ontario Commission acknowledged the difficulties in attempting to accomplish very much through voluntary associations (while recognizing the real advances that have in fact been accomplished by them) ${ }^{21}$

There can be problems as well at the second level, that of institutions per se. To take the Manitoba example, there is no formal mechanism for communication, aside from informal semi-annual meetings between the university and college heads. The stance taken is that the two entities as institutions really do not have much about which to communicate. Within the institutions there is communication between those responsible for the programs that permit some form of transfer. This, moreover, is usually at the department rather than faculty level, and the arrangements are of a rather than faculty level, and the arrangements are of a rather ad hoc nature which does not normally involve formal permanent mechanisms. Thus the university involvement in college program planning is limited to the presence of faculty members on the appropriate program advisory committees of the colleges. But important qualifications must be stated here. Such persons represent academic programs rather than faculties or universities, and, in addition, are but one among many and disparate voices within that advisory mechanism. Furthermore, they have an advisory function only, with a sanctioning authority limited to recommendation back to their home institution to refuse transfer credit: Needless 
to say this would be a rather sensitive political action, with the very sensitivity probably leading to more compromise on the part of the university than it would consider academically desirable. Despite these difficulties, however, there is a genuine reluctance to introduce a coercive element into this discussion format. British Columbia, for example, has a Provincial Post-Secondary Co-ordinating Committee which can review disputes arising in subject committees and present its recommendations as advice to the two institutions concerned. But a 1976 report of the Commission on University Programs in Non-Metropolitan Areas was quite adamant that co-ordination should not be extended further:

The Commission rejects the advice that legislation embodying compulsion be introduced to resolve articulation disputes. In the Commission's opioion it would be both unwise and improper to undermine the autonomy of the institutions in this way. The Commission concurs with the Chairman of the co-ordinating Committee that in the long run, discussion and good-will resolve the issues in dispute. ${ }^{22}$

The difficulties are exacerbated in jurisdictions like British Columbia in which a number of community colleges interacts with three universities in providing a first two years of university study. Here the situation had emerged of courses accepted by one university not being accepted by one or both of the others. As the 1976 Commission concluded ${ }^{23}$ a co-ordinating agency to "articulate" credit transfer arrangements would be rather ineffectual as long as such anomalies exist. And, as suggested above, such anomalies may be endemic to a situation which honours institutional autonomy. Accordingly, that commission identified two other possible modes of articulation: limitation of credit transfer to one existing university; or creation of a new university with that mandate. In a rather surprizing move, the government of British Columbia introduced in 1978 what would in effect be a variation of that second alternative, in proposing the transplantation of the English Open University model. While this approach is hardly likely to find universal acclaim across Canada (even though it appeared in several commission reports), it does underline the important consideration that a situation permitting several universities to negotiate individual arrangements with the colleges of a province can have unfortunate academic consequences. Not least may be a possible temptation to "bargain" in a situation where universities are anxious to maintain their enrolments.

The resolution of college-university relationships will require a clearer articulation than has been presented to date of the academic work appropriate to colleges and universities respectively. The definition of college work is usually similar to that contained in a 1972 report of the New Brunswick Higher Education Commission: ". . . shorter than the usual university programme, more practical in its orientation and content, and more specific in the skills and processes taught." 24 The 1972 Oliver Task Force in Manitoba attempted to differentiate the roles as between, on the one hand, "professional training (especially that which requires mastery, of a large body of theory)" and, on the other hand, "career training that is not heavily dependent on the mastery of theory:" At the same time, however, serious consideration was given to the suggestion that all professional training should be delegated to the colleges; indeed, the notion floundered not on principle but on practicality. In the area of professional training, there is certainly no firm concensus as to the line of demarcation between the areas that should be handled at the college level and those that should be handled at the university level. (The differences of opinion in 
such areas as dental hygiene and occupational therapy, for example, are cases in point.) The problem of distinction is greater still in the area of non-credit continuing or extension education. The first annual report of the Alberta Colleges Commission (1969-70) defined the functions of the so-called "Public Colleges":

(a) to provide the first two years of university transfer programs upon whose completion students may transfer to universities.

(b) to provide technical and vocational career programs of such quality that students will be prepared to enter a vocation upon completion of their college work.

(c) to provide upgrading education for those students who need it to continue to more advanced programs.

(d) to provdie adult and continuing education in vocational, avocational and liberal education courses.

(e) to provide the general education needed by all students regardless of the focus of their other academic or career work. ${ }^{25}$

In answering the first three areas, the colleges were indeed filling a void that bespoke the universities' own feeling that such ventures were inappropriate to their mandate. But the last two areas can be indistinguishable in detail from work traditionally undertaken by the universities (even if, as it is probably quite correctly observed, "university education has not been designed to serve local needs." ${ }^{26}$ ) The resulting competition (understandable in a time of shrinking enrolments) will not diminish by voluntary retreat on either part. It would seem that his area is one in which external co-ordination would not be interferring with academic areas for which the argument of university autonomy is quite so germane, though no real attempt seems yet to have been made to differentiate categories of university work in this fashion. Moreover, any such rationalization of activities would have to ensure some form of financial recompense to the university (if financial need is a principal cause of the duplication). Again, no concrete policies have been formulated in this area,

Another important factor in college-university relations has been the perceived difference in character between the staffs. This is less the case in the junior college-like areas, where the present economic system is resulting in the hiring of exceptionally well qualified staff. Even here, however, there persist some basic differences, most significantly in the academic areas of research and scholarship. To quote from the first annual report of the Alberta Colleges Commission:

The highest priority is placed on proper guidance, counselling and instruction so that the student's educational development will result in an individual serving both his own, his community's and society's needs.

To this end, college teachers tend to be instruction rather than research oriented - somewhat different from the universities approach. ${ }^{27}$

This stance is discomforting to many of the young college staff, and there is some agitation to permit them a closer association with the scholarly activities of the universities. While such a move would undeniably be beneficial in terms of quality of the transfer work (in the sense at least of its being more in line with the work students would be undertaking at the universities), it is problematic whether the special purpose of the colleges per se would be unharmed. It is quite clear that the colleges, even in their junior college function, were not meant to be simply university "branches". In addition to this issue of principle, 
there are, of course, problems of practicality. If the community colleges insist that theirs is essentially a teaching function, the work schedules of the staff will almost inevitably reflect that attitude. (In Manitoba, for example, the work-load of the community college instructor can be compared to that of a high school teacher).

Differences between the two staffs are more pronounced in the technological areas. The college staff are not hired as theorists but as competent practitioners. And there is some feeling that the approach taken by college staff results in a rather different preparation in course areas that superficially would sound virtually identical. An attempt is now being made to secure appropriate information to substantiate or repudiate these feelings, but as yet such data are not available. The significant point, however, is that these unsubstantiated "feelings" are unfortunately all that most university staff know of the colleges and it will thus act as the basis of their reaction to issues related to college-university relationships. When these attitudes are placed beside the negative attitudes of many college staff toward the university "approach", it becomes clear that the problem goes deeper than the facile explanation given by some university people that the issue is just one of relative quality of instruction. It is a matter of two very different perspectives. In example, this tension seems to be reflected in the college students in the joint Bachelor of Education program at the University of Manitoba. These students, more so than the regular university students in the program, have tended to opt for the three years (i.e., two years of college; one of university) required for provincial certification, rather than for the full four years (i.e., two of college and two of university) required for the degree itself.

But here again it is difficult to know whether all of the proper questions have been asked. Study has been made, for example, of the characteristics of college students as opposed to university students (social-economic status, age, attitudes, etc.); but except in the case of the ternary systems, there is no real basis in data to compare the performances of students who transfer to university, or to compare the attitudes of those students on the basis of their college experience. Walter Stein implies an interesting reversal of the normal question (viz., how colleges affect the academic attitude of their students), by suggesting that the attitudes that college students as a unique breed bring to their studies in the first instance almost force an un-university-like mold on their learning experiences and on their instructors, or at least reinforce other influences that are already acting in that direction, even in junior college.

The primary attribute of the post-secondary continuation college is a condition that may be described as institutional anomie. This results from the interaction of a collegial faculty largely independent of external standards with a student population largely indifferent to the Newmanesque ideals of its professors.

Despite the similar attitudes and goals of their respective faculties, the atheneum operates within a student-faculty consensus directed toward the production of abroad and rounded leadership elite. The continuation college, on the other hand, is not supported by consensus since the majority of its students are neither likely to prize the collegial goal, nor are they equipped with the general skills required for its attainment. Hence, faculties at the (continuation college) will complain frequently that their students are illprepared, resistant, and indifferent to learning "for its own sake". The bitterness that attends these complaints hints at frustration and a sense of personal betrayal that faculties experience when they confront students who cannot be moulded to fit the self-image. ${ }^{28}$ 
While this is rather too sweeping a generalization - (it is to be assumed for example, that there would be some important differences between the academic ethos of a junior college and a "binary" system community college) - the conclusions drawn by the writer are of fundamental importance to any plans to wed the two sectors ina joint professional program, as is being attempted at the University of Manitoba.

The movement toward closer association of the various elements comprising postsecondary education in Canada is an inevitable one. Clearly, however, it must be done with a clear appreciation of its limits; and these limits are inherent in the character and purposes of the individual parts. If the approach to closer association is done carefully, it will enhance in an important way the responsiveness of our institutions of post-secondary education to the variety of needs of our changing country. It will enhance as well the ability of each component part to perform its appropriate tasks. Done improperly, it can compromise the purposes for which the community colleges were established; and even more seriously, it can threaten the basic nature of the university.

\section{FOOTNOTES}

1. Gordon Campbell, "Some Comments on Reports of Post-Secondary Commissions in Relation to Community Colleges in Canada", The Canadian Journal of Higher Education, Volume V, Number 3, 1975, p. 55.

2. Ibid.

3. The Learning Society, Report of the Commission on Post-Secondary Education in Ontario, 1972, p. 33.

4. This earlier economic rationale for the institution of community colleges, that of being able to offer the first two years of university work "at a lower cost than it can be done in the university", has now come under question. This can cause a province to consider using existing post-secondary institutions (including universities) to answer various needs usually served by community colleges, rather than set up new institutions.

Higher Education in Nova Scotia, Report of the University Grants Committee, Nova Scotia, for the Year Ending December 31,1970, p. 8.

Report of the Nova Scotia Royal Commission on Education, Public Services and ProvincialMunicipal Relations, 1974, Volume III, Chapter 63, "Special Problems of the University", pp. 44-48.

5. While the rationale for such transfer programs remains valid, it is interesting to note in British Columbia a growing antagonism, on the part of the government and press, toward the principle of community college involvement in academic-transfer work.

cf. John D. Dennison, "University Transfer Program in the Community College", The Canadian Journal of Higher Education, Volume VIII, Number 2, 1978, pp. 27-38.

6. The Learning Society, p. 33.

7. Towards the Learning Community, Report of the Task Force on the Community College, British Columbia, Department of Education, 1974, p. 2.

8. This illustrates one of the difficulties of a "binary" as opposed to "ternary" system as discussed below. The Worth Commission in Alberta, for example, could see the benefit of using the community college for a first year of general education, with a subsequent move to technical institutes for "undiluted" professional training. Manitoba, having the community colleges as its sole technological institutes, does not have that flexibility.

9. Report of the Royal Commission on Education and Youth. Province of Newfoundland and Labrador, Volume 2, 1968, pp. 98-99. 
10. Higher Education in Nova Scotia, Report of the University Grants Committee, Nova Scotia, for the Year Ending December 31, 1970, p. 9.

11. Report of the Task Force on Post-Secondary Education in Manitoba, 1974, p. 46.

12. Maritime Provinces Higher Education Commission, Second Annual Report, 1975-76, p. 12.

13. Report of the Nova Scotia Royal Commission on Education, Public Services and ProvincialMunicipal Relations, 1974, Volume III, Chapter 63, "Special Problems of the University", p. 44.

14. Higher Education in Nova Scotia, Report of the University Grants Committee for the Year Ending December 31, 1970, p. 9.

15. cf. for exemple Jocelyn Desroches, "Authority Conflict in Relation to the Job Satisfaction of Ontario CAAT's Instructors, 'The Canadian Journal of Higher Education, Volume VIII, Number 1, 1978, pp. 33-45.

16. Campbell, op. cit. p. 62; cf. also The Alberta Colleges Commission, First Annual Report, 1969-70, p. 16.

17. Campbell, ibid., p. 55.

18. New Brunswick has the "New Brunswick Community College" as the co-ordinating agency for the individual institutions of the province.

cf. New Brunswick Higher Education Commission, Seventh Annual Report, 1973-74, p. 7.

19. Flexibility for the Seventies, Report of the New Brunswick Higher Education Commission, 1972 , p. 50.

20. The Leaming Society, p. 35.

21. Ibid., p. 117.

22. Report of the Commission on University Programs in Non-Metropolitan Areas, Province of British Columbia, 1976, p. 22.

23. Ibid., p. 39.

24. Flexibility for the Seventies, p. 49.

25. The Alberta Colleges Commission, First Annual Report, 1969-70. p. 23.

26. Flexibility for the Seventies, p. 49.

27. The Alberta Colleges Commission, op. cit.

28. Walter J. Stein, "The Forms of Academe," The Canadian Journal of Higher Education, Volume IV, Number 2, 1974, p. 62. 